\title{
Effect of tillage practices, fertilizer treatments and crop rotation on yield of maize (Zea mays L.) hybrids
}

\author{
Karamchand Bramdeo - Tamás Rátonyi \\ University of Debrecen, Faculty of Agricultural and Food Sciences and Environmental Management, \\ Institute of Land Use, Technology and Regional Development \\ bramdeo@agr.unideb.hu
}

\begin{abstract}
SUMMARY
This research was conducted at the University of Debrecen Látókép Research Station and is part of an ongoing long-term polyfactorial experiment. The impact of three tillage systems (Mouldboard plowing-MT, Strip tillage-ST, Ripper tillage-RT) and two levels of fertilizer treatments $\left(N_{80} \mathrm{~kg} \mathrm{ha}^{-1}, N_{160} \mathrm{~kg} \mathrm{ha}^{-1}\right)$ along with a control $\left(N_{0} \mathrm{~kg} \mathrm{ha}^{-1}\right)$ on the yield of maize hybrids (Armagnac- FAO 490 \& Loupiac-FAO 380) cultivated in rotation with winter wheat was evaluated during a two-year period (2017-2018).

Amongst the three tillage treatments evaluated, ripper tillage $(R T)$ had the highest average yield $\left(10.14 \mathrm{th} \mathrm{h}^{-1}\right)$ followed by mouldboard tillage (MT) and strip tillage (ST) with 9.84 and $9.21 \mathrm{th} \mathrm{h}^{-1}$ respectively. Yield difference between $R T$ and MT was not significant $(P>0.05)$, as compared to $S T(P<0.05)$. Soil moisture content varied significantly with tillage practices and was highest in ST, followed by RT and MT $(S T>R T>M T)$. Yield of RT was 7-9\% higher than MT in monoculture plots, while MT reign superior in biculture plots (monoculture: $R T>M T>S T$; biculture: $M T>R T>S T$ ).

A positive interaction between tillage and fertilization was observed, with higher yield variation $(C V=40.70)$ in the non-fertilized $\left(N_{0}\right)$ plots, compared to those which received the $N_{80}(C V=19.50)$ and $N_{160} \mathrm{~kg} \mathrm{ha}^{-1}(\mathrm{CV}=11.59)$ treatments.

Incremental yield gain from increase fertilizer dosages was significantly higher in monoculture, compared to biculture. There was no significant difference in yield between $N_{160}$ and $N_{80}$ in the biculture plots $\left(12.29 \mathrm{vs} 12.02 \mathrm{th} \mathrm{a}^{-1}\right)$. However, in monoculture plots, $N_{160}$ yield was $23 \%$ higher than the $N_{80} \mathrm{~kg} \mathrm{ha}^{-1}\left(N_{160}=11.74\right.$ vs $\left.N_{80}=9.56 \mathrm{tha}^{-1}\right)$.

Mean yield of maize in rotation with winter wheat was 28\% (2.47 tons) higher than monoculture maize. The greatest benefit of crop rotation was observed in the control plots $\left(N_{0}\right)$ with an incremental yield gain of 4.39 tons hal over monculture maize $\left(9.92 v s 5.43 \mathrm{tha} \mathrm{h}^{-1}\right)$.

Yield increased with higher fertilizer dosages in irrigated plots. Fertilizer application greatly increased the yield of maize and accounted for $48.9 \%$ of yield variances. The highest yield $\left(11.92 \mathrm{th}^{-1}\right)$ was obtained with $N_{160} \mathrm{~kg} \mathrm{ha}^{-1}$ treatment, followed by $\mathrm{N}_{80} \mathrm{~kg} \mathrm{ha}^{-1}\left(10.38 \mathrm{tha^{-1 }}\right)$ and

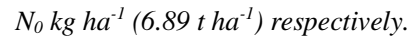

Overall mean yield difference between the two hybrids was not statistically significant, however, yield of FAO 380 was $3.9 \%$ higher (9.06 vs. $8.72 \mathrm{t} \mathrm{ha}^{-1}$ ) than FAO 490 in monoculture plots, while in biculture plots, FAO 490 was $4.1 \%$ higher than FAO 380.

Average yield in 2018 was $13.6 \%$ (1.24 tha $\mathrm{h}^{-1}$ ) higher than 2017 for the same set of agrotechnical inputs, thus, highlighting the significant effect of cropyear.

Armagnac (FAO 490) cultivated in rotation with winter wheat, under ripper tillage and $N_{80} \mathrm{~kg} \mathrm{ha}^{-1}$ is the best combination of treatments for optimum yield.
\end{abstract}

Keywords: maize, mouldboard, strip tillage, ripper tillage, fertilizer, crop rotation

\section{INTRODUCTION}

One of the biggest challenges facing agriculture in the $21^{\text {st }}$ century is the production of adequate food to meet the demand of an increasing world population, constrained by limited arable lands and changing climatic conditions (Abumhadi et al., 2012).

According to FAOSTATS, arable land per capita has significantly decreased over the years, thereby necessitating optimization of land productivity and hence, increased biomass production per unit area, not only under favourable growing conditions, but even more under conditions constrained by climate, water availability and soil quality.

Maize (Zea mays L.) is major grain crop in Hungary, cultivated on approximately one million hectares. Besides being an excellent feed source, maize is also a cheap source of energy and raw material for industry (Nagy, 2006). Annual production over the last decade ranged from 4.8 to 9.3 million tons, with significant fluctuation in yield (Hungarian Central Statistical Office, 2018). Maize has high productivity, but it is very sensitive to the agroecological and agrotechnical conditions. When these conditions are optimal, the amount of yield is determined by the differences between the hybrids; but in the case of unfavourable weather conditions or shortcomings in the agrotechnique, the most important factor is the adaptability of the hybrids (Gardner et al., 1990; Marton et al., 2005).

Harmonization of the agroecological (weather and soil), biological bases and agrotechnical factors is essential for optimizing and stabilizing the yield of maize (Berzsenyi et al., 2011; Sárvári and Bene, 2012). The effects of the agrotechnical factors on the yield stability of maize are especially important and exert their effect via interactions, rather than in isolation (Pepó, 2007). Crop rotation, fertilization, irrigation, plant density, tillage and weed control are amongst the most important elements of maize production (Pepó and Sárvári, 2013) and cropyear was found to strongly modify the effects of these agrotechnical elements.

Tillage is an important agrotechnical input which influences soil physical, chemical and biological 
characteristics, and ultimately plant growth and development (Rashidi and Keshavarzpour, 2009). Changes in soil physical properties, as a result of different tillage practices, influenced seedling emergence, plant population density, root distribution and crop yield (Iqbal, et al., 2013; Khurshid et al., 2006).

Soil tillage systems reportedly had different effects on the preservation of the soil moisture contents, which significantly affected maize yield (Simić et al., 2009) and the most important goals of tillage include preserving the favourable soil attributes and alleviating circumstances leading to detrimental processes.

In Hungary, changing climatic condition and increase frequency of drought years are paving way for alternative tillage methods which can conserve on soil moisture, minimise soil erosion and optimize yield. Mouldboard tillage has been the common practice in Hungary in maize production technology. However, this tillage practice offers minimal soil surface protection with crop residue and has high potential for moisture loss and soil erosion.

Strip tillage (ST) and ripper tillage (RT) are two alternatives which have been identified for evaluation in this research. Unlike the moldboard tillage, strip and ripper implements do not completely invert the soil and leaves a higher percentage of the soil surface covered by crop residue. The potential for erosion and moisture loss is therefore considerably less than of mouldboard plowing. Besides, ripper tillage reportedly loosens more soil, compared to conventional and zero tillage and allows for greater aeration and water retention capacity, which are favourable for plant growth (Memon et al., 2012).

Crop rotations have been found to optimize crop yield potential by improving soil conditions, reducing weeds, diseases and pests populations. It strongly modifies the efficiency of fertilization and can help in the successful use of minimum tillage and decrease the costs of production with fewer inputs (Sárvári and Pepó, 2014). The yields of maize and wheat grown in monoculture were reportedly, always lower than in crop rotation (Vári, 2013).

The yield of maize varies from variety to variety, location to location and also depends on the availability of essential factors such as soil nutrient status and application of fertilizers. Debreczeni (1980) opined that the method and extent of fertilization should be determined not on the basis of maximum yield, but basis of financial gains. Maize absorbs the nutrients partially from the soil and partially from the fertilizers. However, the nutrient demand of maize is satisfied mainly with chemical fertilizers. The applied dose is influenced by several factors which include planned yield level, the nutrient pool and nutrient providing ability of soil, the specific nutrient demand of maize, the water supply of the soil at sowing, the characteristic of the hybrid and preceding crop (Pepó and Csajbók, 2013).

The nutrient demand of maize is pronouncedly high and significant amount of nitrogen is required for the formation of its large vegetative and generative mass.
According to Pepó and Sárvári (2013) the optimal fertilizer dosages on chernozem soil in sustainable maize production is N 100-140 $\mathrm{kg} \mathrm{ha}^{-1}$ and N 140-180 $\mathrm{kg} \mathrm{ha}{ }^{-1}$ for biculture and monoculture maize respectively. Nitrogen deficiency or excess can impact negatively on yield of maize. In non-irrigated treatment $90 \mathrm{~kg} \mathrm{~N} \mathrm{ha}^{-1}$ fertilizer dose was found to be adequate to achieve yield that are close to maximum, while under irrigated condition this can even increase to $120 \mathrm{~kg} \mathrm{~N}$ ha $^{-1}$ (Nagy, 2003).

Bocz and Nagy (1981) reported that optimal Nsupply significantly contributes to grain number per $\mathrm{cob}$, and to a lesser extent increase of thousand grain weight. According to Inamullah et al. (2011), increasing nitrogen levels up to $240 \mathrm{~kg} \mathrm{ha}^{-1}$, increased ears/plant, ear length, grains/ear, 1000 grain weight, biological yield, grain yield and harvest index. Similar results were also reported by Prihar and Stewart (1990).

Pepó and Karancsi (2014) posited that the water utilization of the maize hybrids can be improved with a proper nutrient supply and optimum fertilization. Similar report by Sulyok (2005) showed that higher yields were achieved with $240 \mathrm{~kg} \mathrm{~N}$ in years with good precipitation, compared to dry years, where $240 \mathrm{~kg} \mathrm{~N}$ treatment resulted in yield depression. Nagy (2003) found with higher fertilizer doses, the yield increasing effect of irrigation is also greater and can be explained with the positive correlation between nutrient and water supply. In the case of $120 \mathrm{~kg} \mathrm{~N} \mathrm{ha}^{-1}$, irrigation was found to increase the yield of maize by 1.7 tons $\mathrm{ha}^{-1}$ on average. Under favourable conditions fertilisation could improve yield up to $50 \%$, however in excessively dry years, it does not have any yield increasing effect (Pepó, 2007).

The aim of the research therefore is to determine the best combination of agrotechnical inputs which will optimise the yield of maize hybrids. The findings of this research will add to the body of knowledge gained from similar research and will serve as an effective tool to analyse trends, generate model and predict the most suitable crop production technologies which can be applied, in order to reduce fluctuation in yields and achieve production sustainability.

\section{MATERIALS AND METHODS}

The experiment was conducted at the Látókép

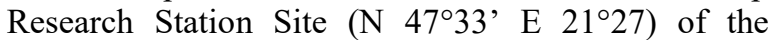
University of Debrecen. The soil type was calcareous chernozem soil, consisting of $11 \%$ sand, $65 \%$ silt and $24 \%$ clay in the upper soil layers, with a near neutral $\mathrm{pH}$ value $\left(\mathrm{pH}_{\mathrm{KCl}}=6.46\right)$. It has a humus content of $2.8 \%$ and humus depth of approximately $80 \mathrm{~cm}$, with good water holding capacity.

The experimental area was 3.0 ha in size with a split-plot design, equally divided into irrigated and nonirrigated, with three main plots representing the tillage treatments (Moldboard tillage (MT)- $30 \mathrm{~cm}$ depth; Strip tillage (ST)- $30 \mathrm{~cm}$ depth; Ripper tillage (RT): $45 \mathrm{~cm}$ depth). The main plots were subdivided to accommodate two fertilizer treatments $\left(\mathrm{N}_{80}\right.$ \& $\mathrm{N}_{160}$ 
$\left.\mathrm{kg} \mathrm{ha}^{-1}\right)$ along with the control $\left(\mathrm{N}_{0} \mathrm{~kg} \mathrm{ha}^{-1}\right)$ which were replicated four times.

Maize hybrids, Loupiac (FAO 380) and Armagnac (FAO 490) were sown at 80,000 seeds ha ${ }^{-1}$ with Gaspardo 6-row automatic planter and a row spacing of $76 \mathrm{~cm}$.
Monthly precipitation and temperature were recorded for the period 2017-2018 and compared to the 50 year mean (Figure 1 ).

Precipitation during the vegetative period (April to September) was $354.4 \mathrm{~mm}$ and $317.9 \mathrm{~mm}$ for 2017 and 2018 respectively, against a 50 year mean of $340.0 \mathrm{~mm}$.

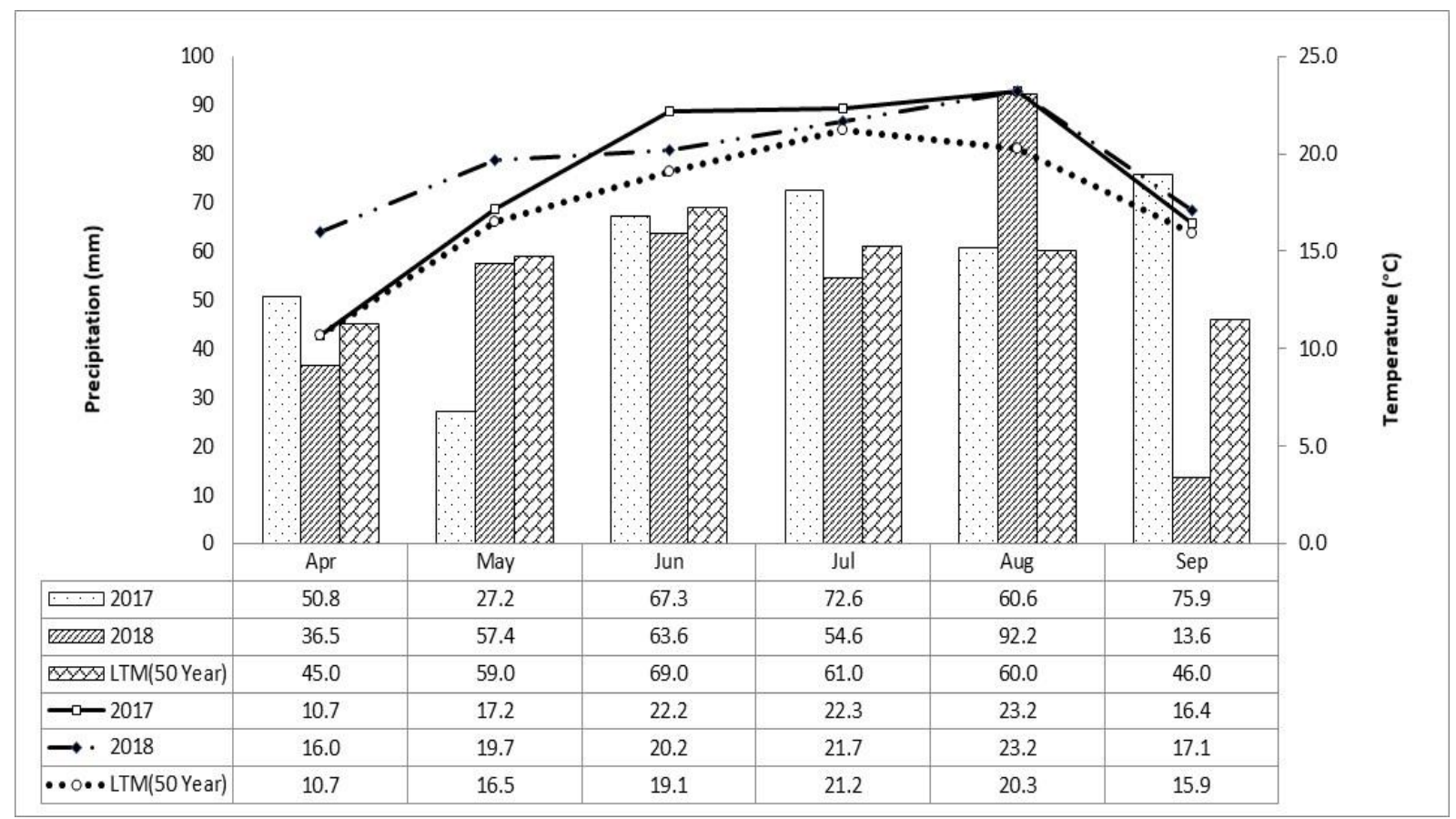

Soil penetration resistance and soil moisture content were measured in the three tillage treatments by a hand operated static cone penetrometer (Penetronik) combined with moisture sensor to a depth of $0.65 \mathrm{~m}$. The experimental plot was harvested by a Sampo plot harvester and yield data analyzed using SPSS 26 and Microsoft Excel.

\section{RESULTS AND DISCUSSION}

Analysis of the meteorological data for the two years (2017 \& 2018), revealed major differences, especially the amount and distribution of rainfall during the growing season (April-Sept). Nagy (2006) observed that higher yields were always accompanied by higher precipitation but low yield was not always accompanied by the lowest amount of precipitation and the most critical period of the growing season in Hungary is between flowering and fertilization $\left(15^{\text {th }}\right.$ July $-15^{\text {th }}$ August) and a period of 3 to 4 days of severe moisture stress at this time can significantly reduce final grain yield.

Based on rainfall distribution and temperature during the growing season, 2018 was a more favourable cropyear relative to 2017 . Mean yield of maize for the period was $9.73 \mathrm{t} \mathrm{ha}^{-1}$ with 2018 yield being $13.6 \%$ $\left(1.24 \mathrm{t} \mathrm{ha}^{-1}\right)$ higher than 2017 for the same set of agrotechnical inputs, thus highlighting the significant effect of cropyear.

Significant effects of the year on the yield and its components were observed very often in long-term field studies due to differences in precipitation and grow degree days accumulation during the vegetative period of maize (Boomsma et al., 2010). Weather regulates heat and moisture supply of the crop environment and therefore has an effect on material transformation, fertilizer efficiency and nutrient uptake by plants (Kovács, 1982; Nagy, 2007).

It was evident that the impact of cropyear on yield of maize was highly significant compared to tillage and crop rotation (Figure 2 ). 
Figure 2: Tillage and forecrop interaction (2017-2018)

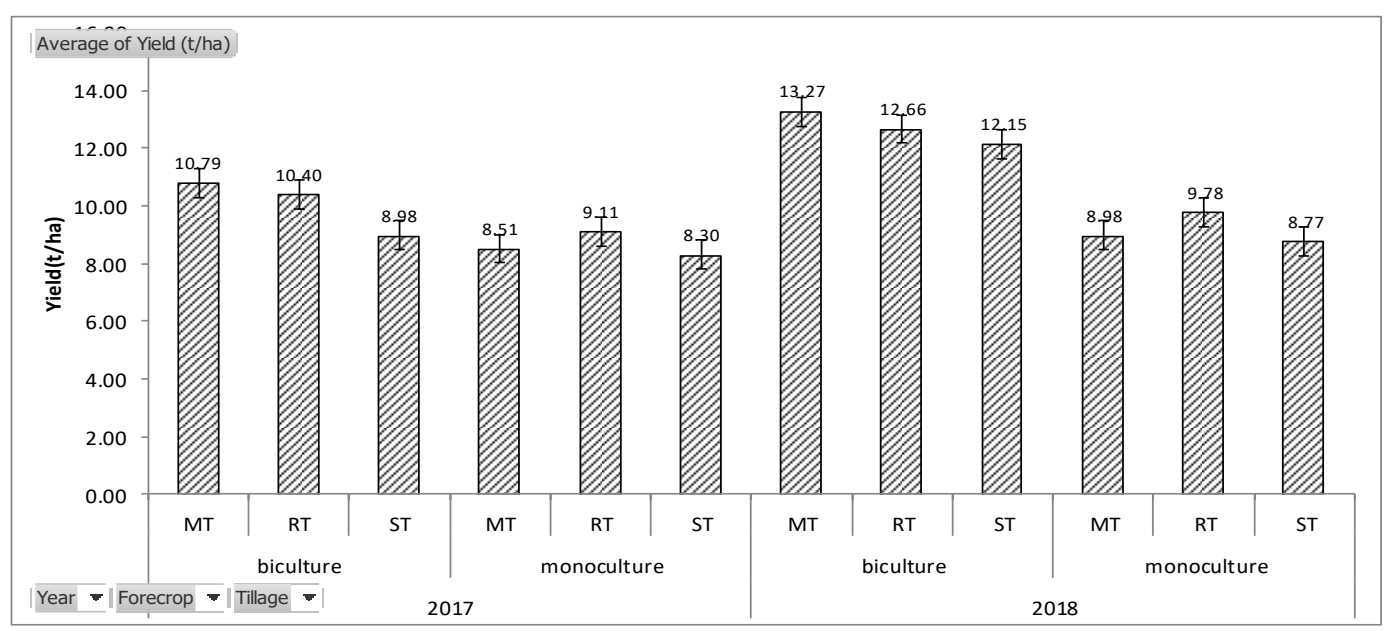

Soil penetration resistance and moisture content varied with tillage treatments. Penetration resistance in all three treatments increased with depth. The highest penetration resistance $(1.7 \mathrm{MPa})$ at $30 \mathrm{~cm}$ depth was measured in the inter-rows of ST, compared to MT and RT with 0.5 and $0.9 \mathrm{MPa}$ respectively. Soil moisture content in the upper $30 \mathrm{~cm}$ was observed to be highest in ST, followed in decreasing order by RT and MT.

Amongst the three tillage treatments, ripper tillage (RT) had the highest average yield (10.14 $\left.\mathrm{t} \mathrm{ha}^{-1}\right)$, followed by mouldboard tillage (MT) and strip tillage (ST) with 9.84 and $9.21 \mathrm{t} \mathrm{ha}^{-1}$ respectively. Overall yield difference between RT and MT was not significant $(\mathrm{P}=0.106)$, as compared to $\mathrm{ST}(\mathrm{P}=0.001)$, however, significant interaction was observed between tillage treatments and forecrop, with yield of RT being 7-9\% higher than MT in monoculture plots, while MT reign superior in biculture plots (winter wheat-maize). Similar observations were made by Al-Kaisi et al. (2015), who reported significant interactions between tillage, cropyears and forecrop, with deep ripping and mouldboard tillage being superior to strip tillage under both monoculture and maize-soybean rotation. The differences in maize yield amongst the three tillage systems in maize-soybean rotation was however, not statistically significant, while in monoculture maize there was significant differences amongst the tillage treatments.

Wang et al. (2015), found deep tillage increased root length density and soil moisture content in the 20 $50 \mathrm{~cm}$ soil layer and higher root length density led to greater uptake of deep soil moisture and absorption of soil $\mathrm{N}$ by the root system lower in the soil profile. As a result, greater crop biomass and grain yield were obtained from deep tillage compared to rotary tillage and non-till. We have also observed an increase in soil moisture content of deep rip tillage (RT) in the 30-50 $\mathrm{cm}$ range as well as a reduction in soil penetration resistance when compared to ST and MT.

It is well established that maize grown in rotation with winter wheat (biculture) generally produced higher yield than monoculture maize. Sárvári and Pepó
(2014) reported biculture crop rotation (wheat-maize) increased yield by $1.58 \mathrm{t} \mathrm{ha}^{-1}$ compared to monculture. Our result showed mean yield of maize in rotation with winter wheat was $28 \%(2.47$ t) higher than monoculture, however, yield gain from crop rotation in 2017 was $1.4 \mathrm{t} \mathrm{ha}^{-1}$, while that in 2018 was $3.51 \mathrm{t} \mathrm{ha}^{-1}$. The greatest benefit of crop rotation was observed in the control plots $\left(\mathrm{N}_{0}\right)$ with an increase in yield of $4.39 \mathrm{t}$ $\mathrm{ha}^{-1}$ over monculture maize (9.92 vs $5.43 \mathrm{t} \mathrm{ha}^{-1}$ ).

There was no significant difference in yield between the two test hybrids, however FAO 490 responded better to crop rotation with average yield being $4.1 \%$ higher than FAO 380 (Table 1).

According to Pepó and Sárvári (2013) crop rotation can allow for reduction in fertiliser application and optimal fertilizer dosages on chernozem soil in sustainable maize production was $\mathrm{N} 100-140 \mathrm{~kg} \mathrm{ha}^{-1}$ for biculture and $\mathrm{N} 140-180 \mathrm{~kg} \mathrm{ha}^{-1}$ for monoculture maize respectively. Our result supported their recommendation, as we have found significant interaction between fertilization and winter wheat forecrop $\quad(\mathrm{P}<0.0001)$ and observed decreasing incremental yield gain from increased fertilizer dosage in biculture, compared to monoculture.

There was no significant difference between the N160 and N80 treatments in biculture (12.29 vs 12.02 $\mathrm{t} \mathrm{ha}^{-1}$ ) and therefore our result is showing that N80 $\mathrm{kg} \mathrm{ha}^{-1}$ in biculture maize can be considered optimum under the prevailing condition of 2017-2018 cropyears.

Interaction between fertilization and irrigation was found to be highly significant. Yield increased with higher fertilizer dosage in irrigated plots. This finding is in keeping with similar observation made Paschalidis et al. (2015). Several other researchers have made similar observations and postulated that a strong and positive relationship exists between fertilization and irrigation (water supply) and both should either increase or decrease simultaneously to achieve optimum results. In our result however, we note irrigation was not necessary in monoculture plots at $\mathrm{N} 80 \mathrm{~kg} \mathrm{ha}^{-1}$ as yield in the non-irrigated plots (rainfed) were higher than that of irrigated plots (Figure 3). 
Yield of maize hybrids under different tillage systems, fertilizer treatments and crop rotation (Debrecen, 2017-2018)

\begin{tabular}{lccccc}
\hline & & \multicolumn{2}{c}{ Monoculture Yield $\left(\mathbf{t ~ h a}^{-\mathbf{1}}\right)$} & \multicolumn{2}{c}{ Maize-winter wheat Yield $\left(\mathbf{t ~ h a}^{-\mathbf{1}}\right)$} \\
Tillage & Fertilizer & FAO 380 & FAO 490 & FAO 380 & FAO 490 \\
\hline \multirow{3}{*}{ MT } & $\mathrm{N}_{0}$ & 4.78 & 4.92 & 10.70 & 11.19 \\
& $\mathrm{~N}_{80}$ & 9.75 & 8.98 & 12.82 & 13.53 \\
& $\mathrm{~N}_{160}$ & 11.88 & 11.85 & 12.86 & 13.02 \\
\hline \multirow{3}{*}{ RT } & $\mathrm{N}_{0}$ & 6.29 & 5.05 & 10.12 & 10.57 \\
& $\mathrm{~N}_{80}$ & 10.63 & 9.53 & 12.45 & 13.06 \\
& $\mathrm{~N}_{160}$ & 12.59 & 12.80 & 12.80 & 13.17 \\
\hline \multirow{3}{*}{$\mathrm{ST}$} & $\mathrm{N}_{0}$ & 5.83 & 4.93 & 8.29 & 11.11 \\
& $\mathrm{~N}_{80}$ & 9.13 & 9.48 & 11.19 & 12.16 \\
\hline
\end{tabular}

Figure 3: Fertiliser, irrigation and forecrop interaction

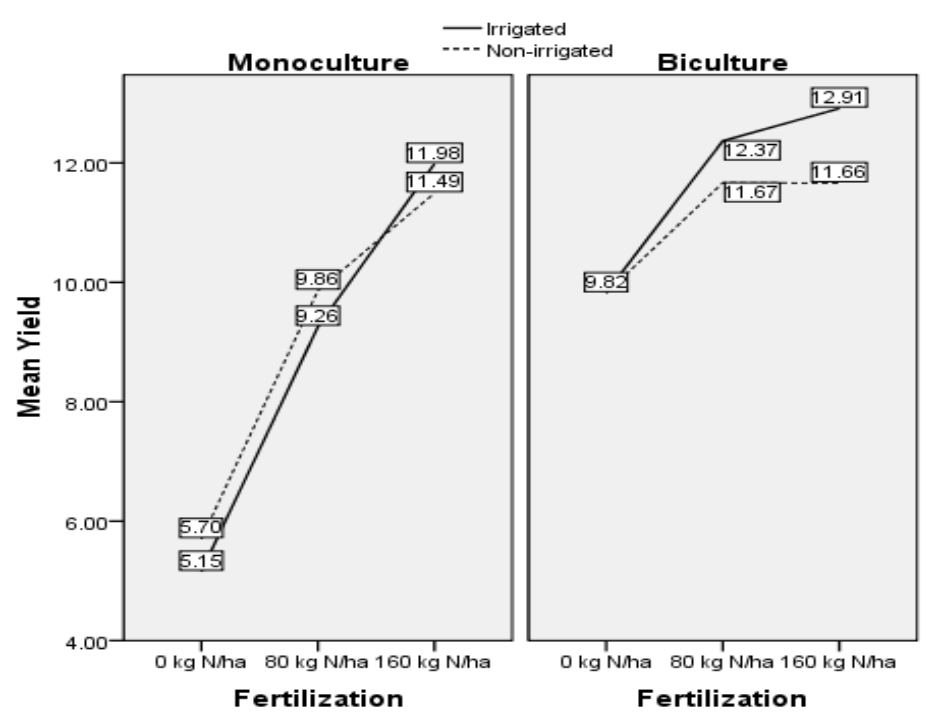

Yield increasing benefit from irrigation in monoculture maize was only realized at N160 level, compared to biculture maize which responded positively to irrigation at both N80 and N160 levels (Figure 3). Incremental yield gain from increase fertiliser dosages was significantly higher in monoculture compared to biculture. The highest incremental yield gain from crop rotation was observed in the control plots $\left(\mathrm{N}_{0}\right)$ and decreased with increase fertilizer dosages.

Amongst the crop production factors analyzed, fertiliser accounted for the largest yield variance of $48.9 \%$, follow in decreasing order by forecrop (14.9\%), hybrids $(2.3 \%)$, tillage $(1.6 \%)$ and irrigation $(<1 \%)$.

\section{CONCLUSIONS}

Armagnac (FAO 490) responded more favorably to crop rotation, compared to Loupiac (FAO 380).
A positive correlation exists between fertilizer dosage and water supply. Irrigation without addition of fertilizer impacted negatively on yield.

Ripper tillage and strip tillage can be suitable alternatives for the conventional mouldboard tillage, especially in drier conditions.

The best combination of treatments for optimum yield was Armagnac (FAO 490), cultivated in rotation with winter wheat, under ripper tillage (RT) and $\mathrm{N}_{80} \mathrm{~kg}$ $\mathrm{ha}^{-1}$ fertilizer.

\section{ACKNOWLEDGEMENTS}

The research was supported by the EFOP-3.6.3VEKOP-16-2017-00008 project and co-financed by the European Union and the European Social Fund. 


\section{REFERENCES}

Abumhadi, N.-Todorovska, E.-Assenov, B.-Tsonev, S.-Vulcheva D.-Vulchev, D.-Atanasova, L.-Savova, S.-Atanassov, A. (2012): Agricultural Research in 21st century: Challenges facing the food security under the impacts of climate change. Bulg. J. Agric. Sci., 18: 801-818.

Al-Kaisi, M.M.-Archontoulis, S.V.-Kwaw-Mensah, D.-Miguez, F. (2015): Tillage and crop rotation effects on corn agronomic response and economic return at seven Iowa locations. Agron. J. 107, 1411-1424.

Berzsenyi, Z.-Arendas, T.-Bonis, P.-Micskei, G.-Sugár, E. (2011) Longterm effect of crop production factors on the yield and yield stability of maize (Zea mays L.) in different years. Acta Agronomica Hungarica. 2011. 59: 3, 191-200.

Bocz, E.-Nagy, J. (1981): Optimizing water and nutrient supply of maize and its effect on the weight of yield. Növénytermelés, 30 . 6. 539-549.

Boomsma, C.R.-Santini, J.B.-West, T.D.-Brewer, J.C.-McIntyre, L.M.-Vyn, T.J. (2010): Maize grain yield responses to plant height variability resulting from crop rotation and tillage system in long-term experiment. Soil and Tillage Research, 106: 227 240.

Debreczeni, B. (1980): Artifical fertilization. Acta Agronomica, 29. $117-225$.

Gardner, F.P.-Valle, R.-McCloud, D.E. (1990): Yield characteristics of ancient races of maize compared to a modern hybrid. Agron. J., 82: 864-868.

Hungarian Central Stats Office (2018): www.ksh.hu. (2019.01.16.)

Inamullah-Rehman, N.-Shah, N.H.-Arif, M.-Saddiq, M.-Mian, I.A (2011): Correlations among grain yield and yield attributes in maize hybrids at various nitrogen levels. Sarhad J. Agric. Vol.27, No.4.

Iqbal, M.-Khan, A.G.-Hassan, A.-Islam, K.R. (2013): Tillage and Nitrogen Fertilization Impact on Irrigated Corn Yields, and Soil Chemical and Physical Properties Under Semiarid Climate. Journal of Sustainable Watershed Science \& Management 1 (3): 90-98.

Khurshid, K.-Iqbal, M.-Arif, M.S.-Nawaz, A. (2006): Effect of tillage and mulch on soil physical properties and growth of maize. Int. J. Agri. Biol., 8: 593-596.

Kovác, G.J. (1982): Critical ecophysical relationship of water and nutrient dynamics of maize. Növénytermelés, 31. 4. 355-365.

Marton, L.-Szundy, T.-Hadi, G.-Pintér, J. (2005): Practical results of the selection to improve the adaptability of maize In.: Adaptability and crop safety of maize hybrids, Debrecen, 139146.

Memon, S.Q.-Mirjat, M.S.-Mughal, A.Q.-Amjad, N. (2012): Effects of different tillage and fertilizer treatments on growth and yield components of maize. Pak. J. Agri., Agril. Eng., Vet. Sci., 2012, 28 (2): 160-176.

Nagy, J. (2003): Effect of Irrigation on Maize Yield (Zea mays L.) Acta Agraria Debreceniensis, 1-6.
Nagy, J. (2006): Evaluation of the effect of crop year on maize yield. Novenytermeles 55(5):299-308.

Nagy, J. (2007): Evaluating the Effect of Year and Fertilisation on the Yield of Mid Ripening (FAO 400-499) Maize Hybrids. Cereal Research Communications, vol. 35, no. 3, 2007, pp. 1497-1507. JSTOR, www.jstor.org/stable/23789855.

Paschalidis, X.-Ioannou, Z.-Mouroutoglou, X.-Koriki, A.Kavvadias, V.-Baruchas, P.-Chouliaras, I--Sotiropoulos, S. (2015): Effect of Fertilization and Irrigation on Plant Mass Accumulation and Maize Production (Zea mays). Int J Waste Resources 5: 173. doi:10.4303/2252-5211.1000173

Pepó, P. (2007): Evaluation of ecological conditions and agrotechnical elements in maize (Zea mays L.) production. Acta Agronomica Ovariensis. 2007. 49: 2(1), 169-175.

Pepó, P.-Csajbók, J. (2013): Integrated Crop Production 1. University of Debrecen. https://www.tankonyvtar.hu.(2019.02.20.)

Pepó, P.-Karancsi, G.L. (2014): New Results of nutrient utilization and response of maize (Zea mays) hybrids. Columella - Journal of Agricultural and Environmental Sciences. Vol. 1, No. 2 (2014) 87-93.

Pepó, P.-Sárvári, M. (2013): Different maize (Zea mays L.) agrotechnical models on chernozem and loamy soils. Analele Universităţii din Oradea, Fascicula Protecţia Mediului Vol. XXI, 2013 156-165.

Prihar, S.S.-Stewart, B.A. (1990): Using upper-bound slope through origin to estimate genetic harvest index. Agronomy Journal 82(6): 1160-1165.

Rashidi, M.-Keshavarzpour, F. (2009): Effect of Different Tillage Methods on Grain Yield and Yield Components of Maize (Zea mays L.), International Journal of Agriculture and Biology. 9 (2): 274-277.

Sárvári, M.-Bene, E. (2012): Maize production factors. Hungarian agriculture 67 (18): 18-21.

Sárvári, M.-Pepó, P. (2014): Effect of production factors on maize yield and yield stability. Cereal Res. Commun. 1(1): 1-11.

Simić, M.-Videnović, Ž.-Dolijanović, Ž.-Jug, D.-Dumanović, Ž. (2009): Maize growing under different tillage systems. 2nd International Scientific/Professional Conference, Agriculture in Nature and Environment Protection, Vukovar, $4^{\text {th }}-6^{\text {th }}$ June, 62 67.

Sulyok, D.Z. (2005): Examining the efficiency of alternative tillage system. PhD thesis, Center for Agricultural and Applied Economic Sciences, University of Debrecen

Vári, E. (2013): International Journal of Chemical, Environmental \& Biological Sciences (IJCEBS) Volume 1, Issue 2 (2013) ISSN 2320-4087

Wang, X.-Zhou, B.-Sun, X.-Yue, Y.-Ma, W.-Zhao, M. (2015): Soil Tillage Management Affects Maize Grain Yield by Regulating Spatial Distribution Coordination of Roots, Soil Moisture and Nitrogen Status. PLoS One. 2015;10(6):e0129231. Published 2015 Jun 22. doi:10.1371/journal.pone.0129231 